\title{
Improved Management Options for Submergence-Tolerant (Sub1) Rice Genotype in Flood-Prone Rainfed Lowlands of West Bengal
}

\author{
Malay K. Bhowmick ${ }^{1}$, Madhab C. Dhara ${ }^{1}$, Sudhanshu Singh ${ }^{2 *}$, Manzoor H. Dar ${ }^{2}$, Uma S. Singh ${ }^{2}$ \\ ${ }^{1}$ Rice Research Station (Government of West Bengal), Chinsurah (R.S.), Hooghly, India; ${ }^{2}$ International Rice Research Institute, New \\ Delhi, India. \\ Email: ${ }^{*}$ sud.singh@irri.org
}

Received October $20^{\text {th }}, 2013$; revised November $16^{\text {th }}, 2013$; accepted November $22^{\text {nd }}, 2013$

Copyright (C) 2014 Malay K. Bhowmick et al. This is an open access article distributed under the Creative Commons Attribution License, which permits unrestricted use, distribution, and reproduction in any medium, provided the original work is properly cited. In accordance of the Creative Commons Attribution License all Copyrights (C) 2014 are reserved for SCIRP and the owner of the intellectual property Malay K. Bhowmick et al. All Copyright (C) 2014 are guarded by law and by SCIRP as a guardian.

\section{ABSTRACT}

Flash flood or submergence is a common phenomenon in rice growing rainfed lowland areas that seriously affects crop establishment leading to severe yield losses. A few submergence-tolerant rice varieties have been developed by introgressing SUB1 gene into mega rice varieties of South Asia. Two of these, Swarna-Sub1 and Sambha Mahsuri-Sub1, are already released in India for the commercial cultivation. Performance of these varieties can be further enhanced through adoption of appropriate management practices both in nursery and in main field. Two on-station field experiments were conducted using Swarna-Sub1 during the wet season (kharif) of 2011 at Rice Research Station, Chinsurah, Hooghly, West Bengal (India). Results of these experiments revealed that the use of lower seeding density $\left(25 \mathrm{~g} \mathrm{~m}^{-2}\right)$, application of balanced doses of $\mathrm{N}_{-} \mathrm{P}_{2} \mathrm{O}_{5}-\mathrm{K}_{2} \mathrm{O} @ 80-40-40$ $\mathrm{kg} \mathrm{ha}^{-1}$ in nursery and transplanting of aged seedlings (44 days) significantly improved plant survival, yield attributing traits and grain yield. An additional N-dose of $20 \mathrm{~kg} \mathrm{ha}^{-1}$ at 7 days after receding of flood water resulted in better post-submergence recovery and maximum grain yield. In the on-farm trials conducted at three different locations in West Bengal, nursery raising of seedlings with the application of $\mathrm{N}_{-}-\mathrm{P}_{2} \mathrm{O}_{5}-\mathrm{K}_{2} \mathrm{O} @$ @0-40-40 $\mathrm{kg} \mathrm{ha}^{-1}$, transplanting them at an optimum age (35 days) and application of $20 \mathrm{~kg} \cdot \mathrm{N} \mathrm{ha}^{-1}$ after 7 days of de-submergence produced maximum grain yield of Swarna-Sub1.

\section{KEYWORDS}

\section{Nursery Management; Post-Flood Nitrogen Management; Submergence; Survival; Swarna-Sub1}

\section{Introduction}

Rice is the major staple food for more than half of the world population and $90 \%$ of it is being produced and consumed in Asia. It is the major crop in most floodprone areas of South and South-East Asia [1]. Flash flood or submergence is a common phenomenon in mainly lowland areas, subject to monsoon rains, seriously affecting crop establishment as well as survival, leading to severe yield losses. It imposes a complex abiotic stress in flood-prone ecosystem, because it substantially reduces crop stand, especially if it occurs during early vegetative stage and prolongs for more than a week [2].

${ }^{*}$ Corresponding author.
The average rice productivity of submergence-prone areas in eastern India is $0.5-0.8$ tonnes $(\mathrm{t}) \mathrm{ha}^{-1}$, whereas it is about $2.0 \mathrm{t} \mathrm{ha}^{-1}$ for favourable rainfed lowlands, being much lower than the input-intensive irrigated system $\left(5.0 \mathrm{t} \mathrm{ha}^{-1}\right)$. However, these flood-prone ecosystems have enormous potential for more food production to meet the ever increasing demands for rice supply because of the predominance of good soils and freshwater resources [3].

West Bengal is one of the eastern states with $2.7 \%$ of the geographical area and about $7.6 \%$ population in India [4], and it ranks first in rice area and production in the country. About $30 \%$ of the rice growing area in this state 
comes under the purview of rainfed lowlands which suffer from frequent flash floods due to erratic distribution of rainfall during wet (kharif) season causing drastic crop yield reduction [5].

The International Rice Research Institute (IRRI) has made considerable progress in developing a Marker Assisted Backcrossing (MABC) system for the major QTL SUBMERGENCE1 (SUB1), associated with submergence tolerance in rice. Through MABC, a number of new varieties have been developed by the introgression of the $S U B 1 A$ gene into mega rice varieties and these new varieties can ensure rice production in flood-prone areas because of their tolerance to complete submergence $[3,6,7]$. However, nutrient recommendations have not been specially developed for flood-prone areas and farmers often avoid using inputs as a risk aversion strategy. The availability of tolerant varieties provides more opportunities for developing and validating proper management options effective in flood-prone areas, which could further boost and stabilize the productivity of these varieties [8-10]. Damage from submergence is most likely when rice plants are small, and the damage seems higher if the plant nutrition is unbalanced. Therefore, improving seedling health in nursery through balanced nutrient management may lead to better crop establishment $[11,12]$. It is unclear if some nutrient elements can actually increase submergence tolerance if applied at rates above balanced applications. Addition of farm yard manure (FYM) can also be helpful for producing robust seedlings. Proper seedbed nutrient management can contribute considerably to maximizing submergence tolerance and grain yield of rice crop in main field [13]. Late transplanting of older and taller seedlings may be another promising option although too old seedlings are less productive. Seed density in rice nursery also needs to be adjusted to avoid weak seedlings. Post-submergence nutrient management can also contribute substantially towards increasing productivity in flood-prone areas [14]. In particular, nitrogen has been reported to be the only possible limiting nutrient for rice production in flood-prone areas [15]. Some of the farmers in these areas usually broadcast a small amount of only nitrogenous fertilizers without following any solid recommendation. Possibilities of recurrent submergence during the season are one of the reasons for avoiding nutrient application $[6,10]$. There exists vast possibility for increasing rice production and harnessing the productivity potentials of submergence-affected areas with the use of submergence-tolerant varieties, particularly when combined with best management practices specific for these areas. Considering this background, we conducted experiments to find out appropriate management options in nursery as well as post-submergence nitrogen management in main field.

\section{Materials and Methods}

Details of field experiments conducted at the Rice Research Station (RRS), Chinsurah (on-station) and as well as at the farmer's fields (on-farm) during wet (kharif) season of 2011 are presented in Table 1.

\subsection{On-Station Experiments}

Two on-station field experiments were conducted during wet (kharif) season of 2011 at the RRS, Chinsurah, Hooghly, West Bengal (India), located at $22^{\circ} 52^{\prime} \mathrm{N}$ latitude and $88^{\circ} 24^{\prime} \mathrm{E}$ longitude with an altitude of $8.62 \mathrm{~m}$ above mean sea level. Soil samples were collected prior to the start of experimentation and analysed using standard protocols [16]. The soil of the experimental site was clay loam having physico-chemical characteristics as described in Table 2. The climate of West Bengal is, in general, tropical and humid which is very conducive for growing rice. The temperature in the mainland normally varies from $24^{\circ} \mathrm{C}$ to $40^{\circ} \mathrm{C}$ during summer and from $7^{\circ} \mathrm{C}$ to $26^{\circ} \mathrm{C}$ during winter. Meteorological data pertaining to the period of experimentation were recorded at the RRS, Chinsurah. Maximum rainfall (more than 90\% of the total) occurred during May-October, ranging from 100.0 $\mathrm{mm}$ to $508.2 \mathrm{~mm}$. The total rainfall in the year was $2116.0 \mathrm{~mm}$, which was $662.3 \mathrm{~mm}$ more than the normal rainfall of $1453.7 \mathrm{~mm}$. Because of heavy rainfall with its uneven distribution, the crop between the age of 2 to 3 months experienced natural submergence twice on September 15, 2011 (40 - $50 \mathrm{~cm}$ depth of water for 6 days) and September 26, 2011 (30 - $40 \mathrm{~cm}$ depth of water for 4 days) (Figure 1).

\subsubsection{Nursery Management (Experiment 1)}

The experiment was laid out in a factorial randomized block design and replicated thrice using the rice variety Swarna-Sub1. Sixteen treatment combinations comprising of two seed densities (D); $\mathrm{D}_{1}: 40 \mathrm{~g} \mathrm{~m}^{-2}$ and $\mathrm{D}_{2}: 25 \mathrm{~g}$ $\mathrm{m}^{-2}$, four levels of nutrient management in nursery (NM); $\mathrm{NM}_{1}$ : N-P $\mathrm{P}_{2} \mathrm{O}_{5}-\mathrm{K}_{2} \mathrm{O} @ 50-25-25 \mathrm{~kg} \mathrm{ha}^{-1}$ as farmers' practice, $\mathrm{NM}_{2}$ : N-P $\mathrm{P}_{2} \mathrm{O}_{5}-\mathrm{K}_{2} \mathrm{O} @$ @80-40-40 kg ha ${ }^{-1}, \mathrm{NM}_{3}$ : $\mathrm{N}-\mathrm{P}_{2} \mathrm{O}_{5}-\mathrm{K}_{2} \mathrm{O} @ 60-40-40 \mathrm{~kg} \mathrm{ha}^{-1}$ and $\mathrm{NM}_{4}: \mathrm{N}-\mathrm{P}_{2} \mathrm{O}_{5}-\mathrm{K}_{2} \mathrm{O}$ @ 40-40-40 kg ha ${ }^{-1}$, and two seedling ages at transplanting (A); $A_{1}: 30$ days and $A_{2}: 44$ days. In each nutrient management treatment, $25 \mathrm{~kg} \mathrm{~N}$ was supplied through $5 \mathrm{t}$ $\mathrm{ha}^{-1}$ of FYM and the remaining $\mathrm{N}, \mathrm{P}$ and $\mathrm{K}$ was supplied through chemical fertilizers.

Staggered nursery seeding at 14 days interval was done to facilitate same day transplanting. The crop was sown in nursery bed on July 18, $2011\left(\mathrm{~A}_{1}\right)$ and July 04, $2011\left(\mathrm{~A}_{2}\right)$, and transplanted in main field on August 17, 2011. Individual plot size was $2 \times 1 \mathrm{~m}$ for nursery bed and $5 \times 4 \mathrm{~m}$ for main field experiments. One-tenth area was used for nursery seeding and accordingly fertilizer 
Table 1. Details of field experiments conducted at RRS, Chinsurah (on-station) and at farmer's fields (on-farm) during wet season of 2011.

\begin{tabular}{lll}
\hline Experiment & Treatments & \\
\hline $\begin{array}{l}\text { On-station experiments } \\
\text { 1) Nursery management }\end{array}$ & a) Seed density (D) & $\mathrm{D}_{1}: 40 \mathrm{~g} \mathrm{~m}^{-2}, \mathrm{D}_{2}: 25 \mathrm{~g} \mathrm{~m}^{-2}$ \\
(Experiment 1) & b) Nutrient management (NM) & $\mathrm{NM}_{1}: 50-25-25, \mathrm{NM}_{2}: 80-40-40, \mathrm{NM}_{3}: 60-40-40, \mathrm{NM}_{4}: 40-40-40$ \\
2) Post-submergence & c) Seedling age (A) & $\mathrm{A}_{1}: 30$ days, $\mathrm{A}_{2}: 44$ days \\
N application & a) Additional dose of nitrogen (N) & $\mathrm{N}_{1}: 10 \mathrm{~kg} \mathrm{ha}{ }^{-1}, \mathrm{~N}_{2}: 20 \mathrm{~kg} \mathrm{ha}^{-1}, \mathrm{~N}_{3}: 30 \mathrm{~kg} \mathrm{ha}^{-1}$ \\
(Experiment 2) & b) Time of application (T) & $\mathrm{T}_{1}: 4 \mathrm{DAD}, \mathrm{T}_{2}: 7 \mathrm{DAD}, \mathrm{T}_{3}: 10 \mathrm{DAD}$ \\
$\begin{array}{l}\text { On-farm experiments } \\
\text { 1) Nursery management (Experiment 1) }\end{array}$ & a) Seedling age (A) & $\mathrm{A}_{1}^{\prime}: 25$ days, $\mathrm{A}_{2}^{\prime}: 35$ days, $\mathrm{A}_{3}^{\prime}: 45$ days \\
2) Post-submergence N application & a) Additional dose of nitrogen (N') & $\mathrm{NM}_{1}^{\prime}: 50-25-25, \mathrm{NM}_{2}^{\prime}: 70-35-35, \mathrm{NM}_{3}^{\prime}: 80-40-40$ \\
(Experiment 2) & applied 7 DAD & $\mathrm{N}_{1}^{\prime}: 10 \mathrm{~kg} \mathrm{ha}^{-1}, \mathrm{~N}_{2}^{\prime}: 20 \mathrm{~kg} \mathrm{ha}^{-1}, \mathrm{~N}_{3}^{\prime}: 30 \mathrm{~kg} \mathrm{ha}^{-1}$ \\
\hline
\end{tabular}

$\mathrm{NM}$ and $\mathrm{NM}^{\prime}$ : Nutrient management in terms of $\mathrm{N}_{2} \mathrm{P}_{2} \mathrm{O}_{5}-\mathrm{K}_{2} \mathrm{O}$ kg ha ${ }^{-1}$; DAD: Days after de-submergence; "Transplanting of 38 days old seedling; ** Transplanting of 35 days old seedling.

Table 2. Soil test report of on-station experimental fields.

\begin{tabular}{lll}
\hline Characteristics & Nursery bed & Main field \\
\hline $\mathrm{pH}$ & 6.70 & 6.90 \\
$\left.\mathrm{EC}(\mathrm{dS} \mathrm{m})^{-1}\right)$ & 0.68 & 0.71 \\
Available $\mathrm{N}\left(\mathrm{Kg} \mathrm{ha}^{-1}\right)$ & 320.00 & 342.00 \\
Available $\mathrm{P}_{2} \mathrm{O}_{5}\left(\mathrm{Kg} \mathrm{ha}^{-1}\right)$ & 46.00 & 48.00 \\
Available $\mathrm{K}_{2} \mathrm{O}\left(\mathrm{Kg} \mathrm{ha}^{-1}\right)$ & 365.00 & 362.00 \\
Organic carbon $(\%)$ & 0.69 & 0.72 \\
\hline
\end{tabular}

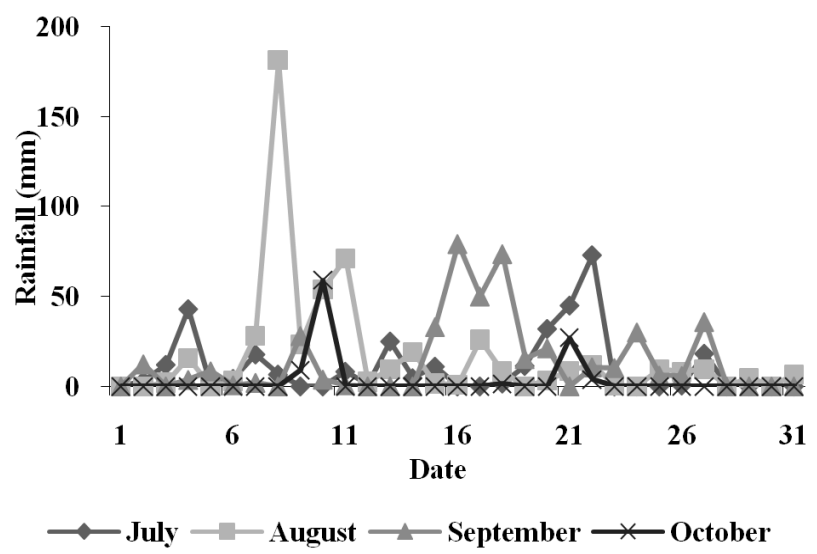

Figure 1. Rainfall receipt during the period of experimentation at RRS, Chinsurah (wet season, 2011).

doses were determined for each treatment plot. Entire amount of nursery fertilizers were applied as basal along with FYM as per treatments. Seeding was done by using pre-germinated seeds and seedlings were transplanted into the field at a spacing of $20 \times 15 \mathrm{~cm}$ with 2 - 3 seedlings hill ${ }^{-1}$ following similar management practices. A common dose of $\mathrm{N}_{-} \mathrm{P}_{2} \mathrm{O}_{5}-\mathrm{K}_{2} \mathrm{O}$ at $80-40-40 \mathrm{~kg}$ ha ${ }^{-1}$ along with $25 \mathrm{~kg} \mathrm{ZnSO} \mathrm{Zn}_{4} \cdot 7 \mathrm{H}_{2} \mathrm{O} \mathrm{ha}{ }^{-1}$ was used in main field. One-fourth dose of $\mathrm{N}$, full doses of phosphate and potash along with full dose of $\mathrm{Zn}$ were added as basal at one day before transplanting. The half of recommended $\mathrm{N}$ dose was applied at active tillering (AT) stage and the re- maining one-fourth of total $\mathrm{N}$ at panicle initiation (PI) stage.

\subsubsection{Post-Submergence Nitrogen Management (Experiment 2)}

Post-submergence nitrogen management included two sets of treatments: a) three additional doses of nitrogen (N); $\mathrm{N}_{1}: 10 \mathrm{~kg} \mathrm{ha}^{-1}, \mathrm{~N}_{2}: 20 \mathrm{~kg} \mathrm{ha}^{-1}$ and $\mathrm{N}_{3}: 30 \mathrm{~kg} \mathrm{ha}^{-1}$ and $b)$ three different times of application $(\mathrm{T}) ; \mathrm{T}_{1}$ : when $10-15 \%$ plants started showing at least one green leaf after de-submergence (4 days after de-submergence, DAD), $\mathrm{T}_{2}$ : when $30 \%-35 \%$ plants started showing at least one green leaf after de-submergence (7 DAD) and $\mathrm{T}_{3}$ : when $65 \%-70 \%$ plants started showing at least one green leaf after de-submergence (10 DAD). The crop was sown in nursery bed on June 28, 2011 and transplanted in main field on August 05, 2011. All the treatments were assigned in a factorial randomized complete block design with three replications. Seeding was done by using pregerminated seeds and seedlings were transplanted into the field at a spacing of $20 \times 15 \mathrm{~cm}$ with $2-3$ seedlings hill ${ }^{-1}$. A common dose of $\mathrm{N}-\mathrm{P}_{2} \mathrm{O}_{5}-\mathrm{K}_{2} \mathrm{O} @ 80-40-40 \mathrm{~kg}$ $\mathrm{ha}^{-1}$ along with $25 \mathrm{~kg} \mathrm{ZnSO} \cdot 7 \mathrm{H}_{2} \mathrm{O} \mathrm{ha}^{-1}$ was used following the similar schedule of nutrient application as for main field in Experiment 1. Additional dose of $\mathrm{N}$ was applied only after de-submergence as per treatment schedule in addition to the recommended fertilizer dose.

\subsection{On-Farm Experiments}

On-farm experiments were also simultaneously taken up in the same crop season with Swarna-Sub1 to ascertain the effect of selective treatments in farmers' fields.

\subsubsection{Nursery Management (Experiment 1)}

In four farmers' fields located at the village Belle under Pandua Block, Hooghly, West Bengal, trials of seedling age for transplanting were organized, keeping individual 
plot size of $200 \mathrm{~m}^{2}$ for each seedling age treatment ( $\left.\mathrm{A}^{\prime}\right)$; $\mathrm{A}_{1}^{\prime}: 25$ days, $\mathrm{A}_{2}^{\prime}: 35$ days and $\mathrm{A}_{3}^{\prime}: 45$ days. Three farmers of the village Digha (Dwarbasini) in the same block evaluated the nutrient management aspect in nursery bed of $10 \mathrm{~m}^{2}$ for each treatment. Three levels of $\mathrm{N}-\mathrm{P}_{2} \mathrm{O}_{5}-\mathrm{K}_{2} \mathrm{O}$ $\left(\mathrm{NM}^{\prime}\right) ; \mathrm{NM}_{1}^{\prime}: 50-25-25 \mathrm{~kg} \mathrm{ha}^{-1}$ (farmers' practice), $\mathrm{NM}_{2}^{\prime}$ : 70-35-35 $\mathrm{kg} \mathrm{ha}^{-1}$ and $\mathrm{NM}_{3}^{\prime}: 80-40-40 \mathrm{~kg} \mathrm{ha}^{-1}$ were used for nursery raising. In each nutrient management treatment, $25 \mathrm{~kg} \mathrm{~N}$ was supplied through $5 \mathrm{tha}^{-1}$ of FYM and the remaining $\mathrm{N}, \mathrm{P}$ and $\mathrm{K}$ was supplied through chemical fertilizers. These seedlings were subsequently transplanted in main field with plot size of $100 \mathrm{~m}^{2}$ for individual nursery treatment, following similar management practices. All the farmers' field trials of Pandua Block faced natural submergence due to flash flood with water depth of $40-50 \mathrm{~cm}$ for $4-7$ days at 40 days after transplanting (DAT).

\subsubsection{Post-Submergence Nitrogen Management (Experiment 2)}

At seven farmers' fields of the village Baidyabati Chawk, Serampore-Uttarpara Block, Hooghly, West Bengal, the effect of additional N-doses, applied at 7 DAD, was studied, keeping individual plot size of $100 \mathrm{~m}^{2}$ for each treatment. On-farm trials at the village faced flash floods at 43 DAT causing submergence with water depth of 60 $70 \mathrm{~cm}$ for 10 days.

All the participatory farmers of three different villages applied a common dose of $\mathrm{N}^{-} \mathrm{P}_{2} \mathrm{O}_{5}-\mathrm{K}_{2} \mathrm{O} @ 80-40-40 \mathrm{~kg}$ $\mathrm{ha}^{-1}\left(25 \mathrm{~kg} \mathrm{~N}\right.$, full $\mathrm{P}_{2} \mathrm{O}_{5}, 3 / 4 \mathrm{~K}_{2} \mathrm{O}$ as basal; $30 \mathrm{~kg} \mathrm{~N}$ through urea at AT stage and $25 \mathrm{~kg} \mathrm{~N}+1 / 4 \mathrm{~K}_{2} \mathrm{O}$ at PI stage) in main fields.

\subsection{Observations Recorded and Statistical Analysis}

In the on-station experiments, observations in terms of survival and growth measurements were recorded in nursery and main field experiments. In nursery, ten seedlings were randomly uprooted from each plot to observe the oven dry weight for calculating dry matter accumulation (DMA). Root and shoot lengths of seedlings were also recorded at the same time. Survival was recorded at 21 DAD. Numbers of tillers hill ${ }^{-1}$ under each treatment was noted at 25 and 45 DAT. Observations on various growth parameters, phenology and data on yield and yield components were recorded at maturity. For on-farm experiments, data on number of panicles $\mathrm{m}^{-2}$, number of filled grains panicle ${ }^{-1}$ and grain yield $\left(\mathrm{t} \mathrm{ha}^{-1}\right)$ were recorded. These data for on-farm trials were simply averaged out and presented along with standard deviations. Whereas, on-station experimental data was analysed with Fisher's ANOVA using the MSTAT-C statistical computer package. The least significant difference (LSD) at
$5 \%$ probability was used to compare means of the treatments [17].

\section{Results and Discussion}

\subsection{Experiment 1: Nursery Management}

\subsubsection{On-Station Experiments}

1) Effect of seed density: Use of lower seed density of $25 \mathrm{~g} \mathrm{~m}^{-2}\left(\mathrm{D}_{2}\right)$ offered better seedling vigour in terms of high DMA (1.04 $\mathrm{g}$ seedling $\left.^{-1}\right)$ and root length $(16.03 \mathrm{~cm})$ at the time of transplanting (Table 3 ). Significantly better performance of the seedlings so produced $\left(\mathrm{D}_{2}\right)$ was reflected in main field also in terms of their survival (94.27\%), plant height $(103.96 \mathrm{~cm})$, root length $(22.05$ $\mathrm{cm})$ and number of tillers produced $\mathrm{m}^{-2}$ (210.92 and 357.08 at 25 and 45 DAT, respectively) (Table 4). Significant effect of seed density was also observed on all the yield components of Swarna-Sub1 (Table 5); however, days to $50 \%$ flowering and days to maturity did not show any significant variation due to treatment effects (Figure 2(a)). Significantly higher grain yield (5.29 t $\mathrm{ha}^{-1}$ ) was produced (Table 5) when seeding was done using lower seed rate $\left(25 \mathrm{~g} \mathrm{~m}^{-2}\right)$ in comparison to that with higher seed rate of $40 \mathrm{~g} \mathrm{~m}^{-2}\left(\mathrm{D}_{1}\right)$. Lower seeding rates in nursery were beneficial for better seedling vigour [13] and seedling vigour was earlier reported to be an important contributor to subsequent tillering quality and yield of rice [18]. Proper seeding density and nutrient management are the key considerations for obtaining strong seedlings which would produce more number of large panicles, whereas, weak seedlings under dense sowing would have less or no tillers [19].

Table 3. Effect of seed density, nursery nutrient management and seedling age on seedling growth at final uprooting from nursery during wet season of 2011.

\begin{tabular}{|c|c|c|c|}
\hline Treatments & $\begin{array}{c}\text { DMA } \\
\left(\text { g seedling }^{-1}\right)\end{array}$ & $\begin{array}{c}\text { Root } \\
\text { length } \\
(\mathrm{cm})\end{array}$ & $\begin{array}{r}\text { Shoot } \\
\text { length } \\
(\mathrm{cm})\end{array}$ \\
\hline \multicolumn{4}{|l|}{ Seed density $(D)$} \\
\hline $\mathrm{D}_{1}: 40 \mathrm{~g} \mathrm{~m}^{-2}$ & 0.73 & 15.65 & 21.58 \\
\hline $\mathrm{D}_{2}: 25 \mathrm{~g} \mathrm{~m}^{-2}$ & 1.04 & 16.03 & 21.80 \\
\hline $\operatorname{LSD}(\mathrm{P}=0.05)$ & 0.09 & 0.34 & NS \\
\hline \multicolumn{4}{|c|}{ Nutrient management $(N M)$} \\
\hline $\mathrm{NM}_{1}: 50-25-25 \mathrm{~kg} \mathrm{ha}^{-1}$ & 0.77 & 15.72 & 21.67 \\
\hline $\mathrm{NM}_{2}: 80-40-40 \mathrm{~kg} \mathrm{ha}^{-1}$ & 1.11 & 16.38 & 22.23 \\
\hline $\mathrm{NM}_{3}: 60-40-40 \mathrm{~kg} \mathrm{ha}^{-1}$ & 0.93 & 15.39 & 21.57 \\
\hline $\mathrm{NM}_{4}: 40-40-40 \mathrm{~kg} \mathrm{ha}^{-1}$ & 0.72 & 15.87 & 21.28 \\
\hline $\operatorname{LSD}(\mathrm{P}=0.05)$ & 0.13 & 0.49 & 0.36 \\
\hline \multicolumn{4}{|l|}{ Seedling age $(A)$} \\
\hline $\mathrm{A}_{1}: 30$ days & 0.84 & 15.71 & 21.65 \\
\hline $\mathrm{A}_{2}: 44$ days & 0.93 & 15.97 & 21.72 \\
\hline $\operatorname{LSD}(P=0.05)$ & 0.09 & NS & NS \\
\hline
\end{tabular}

DMA: Dry matter accumulation; NM: Nutrient management in terms of $\mathrm{N}-\mathrm{P}_{2} \mathrm{O}_{5}-\mathrm{K}_{2} \mathrm{O}$; NS: Not significant. 
Table 4. Effect of nursery management and post-flood nitrogen management treatments on survival and growth of Swarna-Sub1 during wet season of 2011.

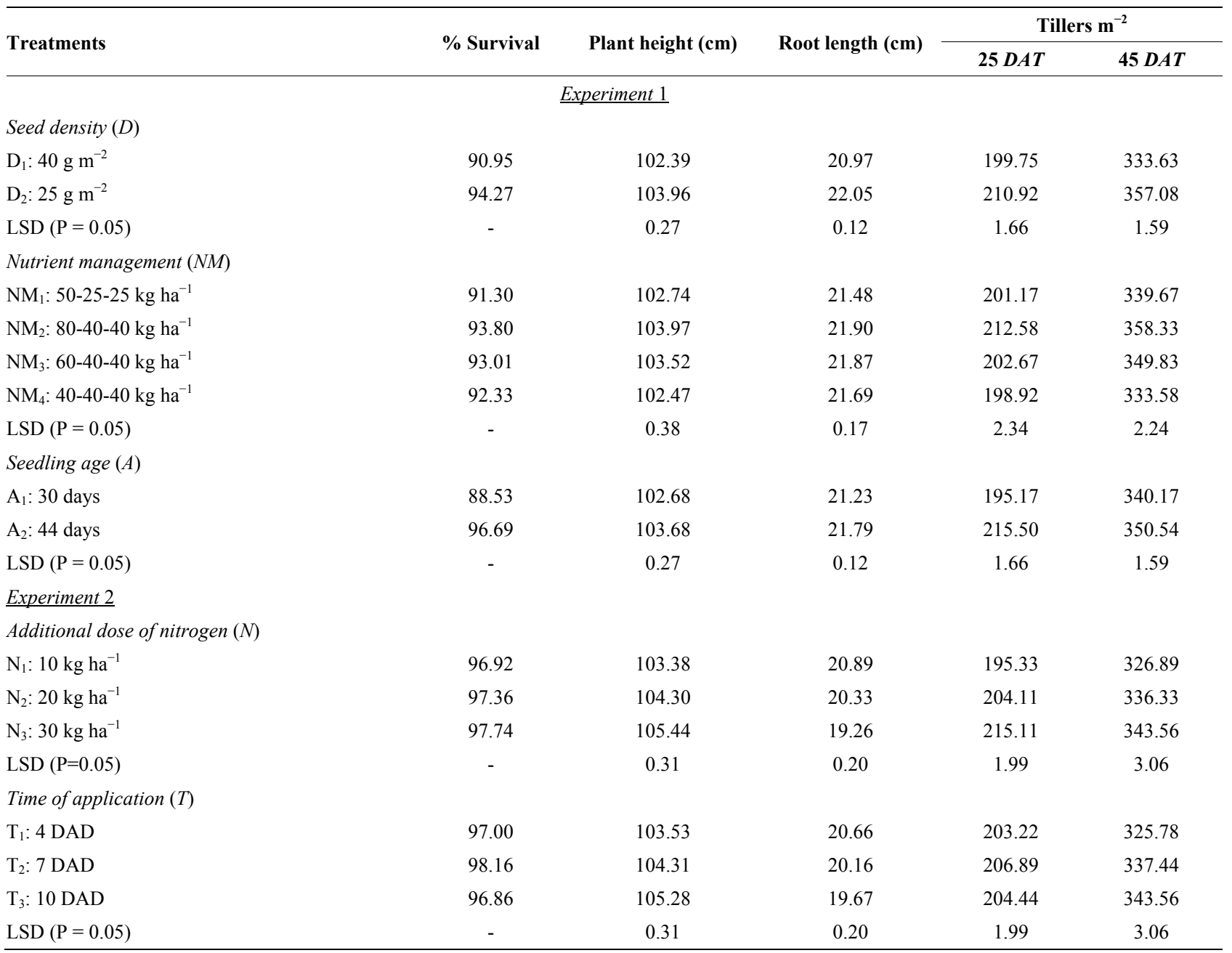

DAD: Days after de-submergence; DAT: Days after transplanting; NM: Nutrient management in terms of N-P $\mathrm{P}_{5}-\mathrm{K}_{2} \mathrm{O}$.

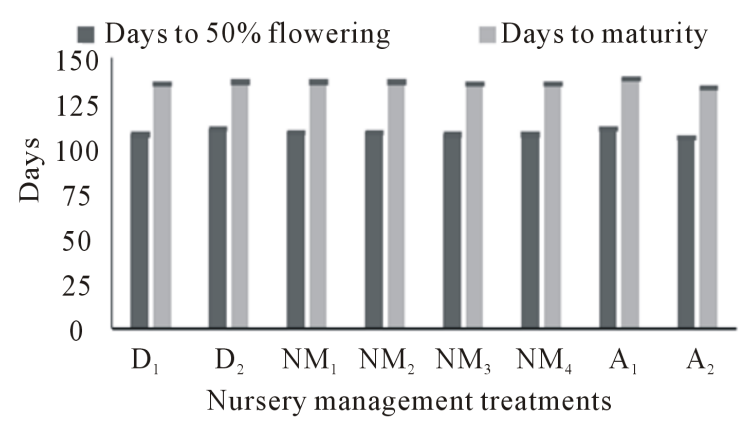

(a)

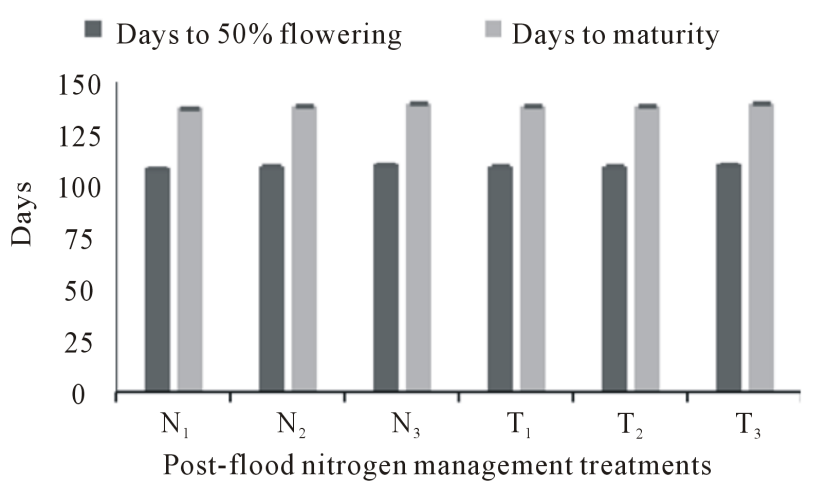

(b)

Figure 2. (a) Effect of nursery management treatments on the days to $50 \%$ flowering and days to maturity of Swarna-Sub1 (On-station experiment 1), (Seed density- $D_{1}: 40 \mathrm{~g} \mathrm{~m}^{-2}, D_{2}: 25 \mathrm{~g} \mathrm{~m}^{-2}$, Nutrient management $\mathrm{NM}-\mathrm{NM}_{1}: 50-25-25 \mathrm{~kg} \mathrm{ha}^{-1}$, $\mathrm{NM}_{2}: 80-40-40 \mathrm{~kg} \mathrm{ha}^{-1}, \mathrm{NM}_{3}: 60-40-40 \mathrm{~kg} \mathrm{ha}^{-1}, \mathrm{NM}_{4}: 40-40-40 \mathrm{~kg} \mathrm{ha}^{-1}$, Seedling age- $A_{1}: 30$ days, $A_{2}: 44$ days); (b) Effect of post-submergence $\mathrm{N}$ application treatments on the days to $50 \%$ flowering and days to maturity of Swarna-Sub1 (On-station experiment 2), (Additional dose of $N-N_{1}: 10 \mathrm{~kg} \mathrm{ha}^{-1}, N_{2}: 20 \mathrm{~kg} \mathrm{ha}^{-1}, N_{3}: 30 \mathrm{~kg} \mathrm{ha}^{-1}$, Time of application-T $T_{1}: 4$ days after de-submergence, $T_{2}: 7$ days after de-submergence, $T_{3}: 10$ days after de-submergence). 
Table 5. Effect of nursery management and post-flood nitrogen management treatments on yield and yield components of Swarna-Sub1 during wet season of 2011.

\begin{tabular}{|c|c|c|c|c|c|c|c|c|}
\hline Treatments & $\begin{array}{c}\text { Panicle length } \\
(\mathrm{cm})\end{array}$ & $\begin{array}{c}\text { Panicles } \\
\mathbf{m}^{-2}\end{array}$ & $\begin{array}{c}\text { Filled grains } \\
\text { panicle }^{-1}\end{array}$ & $\%$ Sterility & $\begin{array}{c}\text { 1000-grain } \\
\text { weight }(\mathrm{g})\end{array}$ & $\begin{array}{c}\text { Grain yield } \\
\left(\mathrm{t} \mathrm{ha}^{-1}\right)\end{array}$ & $\begin{array}{c}\text { Straw yield } \\
\left(\mathrm{t} \mathrm{ha}^{-1}\right)\end{array}$ & HI \\
\hline \multicolumn{9}{|c|}{ Experiment 1} \\
\hline \multicolumn{9}{|l|}{ Seed density $(D)$} \\
\hline $\mathrm{D}_{1}: 40 \mathrm{~g} \mathrm{~m}^{-2}$ & 22.47 & 298.38 & 100.67 & 17.93 & 19.55 & 4.86 & 6.16 & 0.442 \\
\hline $\mathrm{D}_{2}: 25 \mathrm{~g} \mathrm{~m}^{-2}$ & 23.39 & 312.46 & 108.42 & 16.73 & 19.94 & 5.29 & 7.10 & 0.427 \\
\hline $\operatorname{LSD}(P=0.05)$ & 0.13 & 1.27 & 1.15 & 0.14 & 0.03 & 0.06 & 0.05 & 0.003 \\
\hline \multicolumn{9}{|c|}{ Nutrient management (NM) } \\
\hline $\mathrm{NM}_{1}: 50-25-25 \mathrm{~kg} \mathrm{ha}^{-1}$ & 22.90 & 303.17 & 103.50 & 17.48 & 19.62 & 5.00 & 6.42 & 0.439 \\
\hline $\mathrm{NM}_{2}: 80-40-40 \mathrm{~kg} \mathrm{ha}^{-1}$ & 23.71 & 312.67 & 109.08 & 16.51 & 19.99 & 5.39 & 7.15 & 0.430 \\
\hline $\mathrm{NM}_{3}: 60-40-40 \mathrm{~kg} \mathrm{ha}^{-1}$ & 22.97 & 307.50 & 105.83 & 17.33 & 19.83 & 5.17 & 6.79 & 0.433 \\
\hline $\mathrm{NM}_{4}: 40-40-40 \mathrm{~kg} \mathrm{ha}^{-1}$ & 22.13 & 298.33 & 99.75 & 18.00 & 19.54 & 4.76 & 6.16 & 0.436 \\
\hline $\operatorname{LSD}(\mathrm{P}=0.05)$ & 0.18 & 1.80 & 1.62 & 0.19 & 0.04 & 0.08 & 0.07 & 0.005 \\
\hline \multicolumn{9}{|l|}{ Seedling age $(A)$} \\
\hline $\mathrm{A}_{1}: 30$ days & 23.11 & 301.92 & 102.25 & 17.73 & 19.63 & 4.92 & 6.23 & 0.442 \\
\hline $\mathrm{A}_{2}: 44$ days & 22.75 & 308.92 & 106.83 & 16.93 & 19.86 & 5.23 & 7.02 & 0.427 \\
\hline $\operatorname{LSD}(P=0.05)$ & 0.13 & 1.27 & 1.15 & 0.14 & 0.03 & 0.06 & 0.05 & 0.003 \\
\hline \multicolumn{9}{|c|}{ Experiment 2} \\
\hline \multicolumn{9}{|c|}{ Additional dose of nitrogen $(N)$} \\
\hline $\mathrm{N}_{1}: 10 \mathrm{~kg} \mathrm{ha}^{-1}$ & 22.61 & 296.55 & 118.55 & 17.20 & 19.66 & 5.79 & 8.30 & 0.404 \\
\hline $\mathrm{N}_{2}: 20 \mathrm{~kg} \mathrm{ha}^{-1}$ & 23.30 & 310.33 & 121.55 & 16.09 & 20.08 & 6.00 & 8.56 & 0.403 \\
\hline $\mathrm{N}_{3}: 30 \mathrm{~kg} \mathrm{ha}^{-1}$ & 23.27 & 309.11 & 113.00 & 16.84 & 19.95 & 5.95 & 9.30 & 0.406 \\
\hline $\operatorname{LSD}(P=0.05)$ & 0.20 & 5.15 & 2.30 & - & 0.06 & 0.05 & 0.10 & 0.004 \\
\hline \multicolumn{9}{|l|}{ Time of application $(T)$} \\
\hline $\mathrm{T}_{1}: 4 \mathrm{DAD}$ & 22.44 & 300.44 & 115.78 & 16.61 & 19.71 & 5.76 & 7.89 & 0.411 \\
\hline $\mathrm{T}_{2}: 7 \mathrm{DAD}$ & 23.25 & 312.33 & 121.22 & 15.22 & 20.83 & 6.07 & 9.00 & 0.412 \\
\hline $\mathrm{T}_{3}: 10 \mathrm{DAD}$ & 23.49 & 303.22 & 116.11 & 18.30 & 19.89 & 5.90 & 9.28 & 0.390 \\
\hline $\operatorname{LSD}(\mathrm{P}=0.05)$ & 0.20 & 5.15 & 2.30 & - & 0.06 & 0.05 & 0.10 & 0.004 \\
\hline
\end{tabular}

DAD: Days after de-submergence; HI: Harvest index; NM: Nutrient management in terms of $\mathrm{N}_{-} \mathrm{P}_{2} \mathrm{O}_{5}-\mathrm{K}_{2} \mathrm{O}$.

2) Effect of nutrient management: The levels of nutrient management in nursery had a significant impact on growth, yield attributes and grain and straw yields (Tables 4 and 5) except days to $50 \%$ flowering and maturity (Figure 2(a)). Application of the nutrient dose of N$\mathrm{P}_{2} \mathrm{O}_{5}-\mathrm{K}_{2} \mathrm{O} @$ @ 80-40-40 kg ha ${ }^{-1}\left(\mathrm{NM}_{2}\right)$ in nursery significantly recorded better seedling vigour (Table 3), more survival after submergence (93.80\%) and improved crop stand (Table 4), thereby producing significantly higher grain yield of $5.39 \mathrm{tha}^{-1}$ and straw yield of $7.15 \mathrm{t} \mathrm{ha}^{-1}$ in main field, compared with the other treatments (Table 5). In respect of yield performance, next in order were $\mathrm{NM}_{3}$ and $\mathrm{NM}_{1}$, being $\mathrm{N}-\mathrm{P}_{2} \mathrm{O}_{5}-\mathrm{K}_{2} \mathrm{O} @$ 60-40-40 and 50-25-25 $\mathrm{kg} \mathrm{ha}^{-1}$ respectively. Moreover, application of at least 25 $\mathrm{kg} \mathrm{N}$ ha $^{-1}$ through $5 \mathrm{t} \mathrm{FYM} \mathrm{ha}^{-1}$ and the remaining amount of recommended $\mathrm{N}$ dose through inorganic fertilizer might be considered useful, irrespective of nutrient levels. Balanced application of $\mathrm{N}-\mathrm{P}_{2} \mathrm{O}_{5}-\mathrm{K}_{2} \mathrm{O}$ in nursery application were beneficial $[13,20,21]$.
3) Effect of seedling age: A significant gain was observed only in DMA (0.93 $\left.\mathrm{g}^{\text {seedling }}{ }^{-1}\right)$ by nursery seedlings when aged seedlings of 44 days were used (Table 3). The effect of aged seedlings was significantly reflected in main field with regard to better crop survival after submergence, improvement of crop stand and growth (Table 4), days to $50 \%$ flowering and maturity (Figure 2(a)), grain and straw yields along with major yield components (Table 5). All the above and below ground characteristics of rice plants, before and after transplanting, would vary with seedling age [22,23], growing environment [24] and seeding rate [25]. Seedling age might be directly related to survival after submergence. Older seedlings were more tolerant to complete submergence, because of higher vigour and mature tissues, lower underwater shoot elongation and high carbohydrate content than younger seedlings $[10,26]$. Seedling age of 44 days was found to record the highest grain yield of $5.23 \mathrm{t} \mathrm{ha}^{-1}$ and straw yield of $7.02 \mathrm{t} \mathrm{ha}^{-1}$ after 
submergence stress when compared to younger seedlings of 30 days (Table 5 ).

\subsubsection{On-Farm Experiments}

Higher grain yields along with yield components were observed using an optimum seedling age of 35 days (Table 6) in all four farmers' field trials at the village Belle. Yield advantages of 21.2 and $22.0 \%$ were obtained with the use of 35-day old seedlings $\left(\mathrm{A}_{2}{ }^{\prime}\right)$, when compared with $25\left(\mathrm{~A}_{1}{ }^{\prime}\right)$ and 45 days $\left(\mathrm{A}_{3}{ }^{\prime}\right)$ old seedlings, respectively. Late transplanting of older and taller seedlings might be a promising option although the results showed that the too old seedlings were less productive and might not be of added advantage, if not exposed to moderate to severe submergence stresses. Application of $\mathrm{N}-\mathrm{P}_{2} \mathrm{O}_{5}-\mathrm{K}_{2} \mathrm{O}$ $\left(\mathrm{NM}_{3}{ }^{\prime}\right)$ at $80-40-40 \mathrm{~kg} \mathrm{ha}{ }^{-1}(25 \mathrm{~kg} \cdot \mathrm{N}$ through $5 \mathrm{t} \mathrm{FYM}$ $\mathrm{ha}^{-1}$ and the others through chemical fertilizers) in nursery brought about the highest grain yield $\left(4.93 \mathrm{tha}^{-1}\right)$ in main field, exhibiting yield advantages of 7.1 and $19.2 \%$ over $\mathrm{NM}_{2}^{\prime}$ and $\mathrm{NM}_{1}^{\prime}$, respectively. Similar trend was reflected on yield components too (Table 6).

\subsection{Experiment 2: Post-Submergence Nitrogen Management \\ 3.2.1. On-Station Experiments}

1) Effect of additional nitrogen dose: Additional postflood application of 20 and $30 \mathrm{~kg} \mathrm{~N} \mathrm{ha}^{-1}$ could record almost at par increase in crop survival, plant height and number of tillers $\mathrm{m}^{-2}$ over $10 \mathrm{~kg} \mathrm{~N} \mathrm{ha}^{-1}$, indicating that the treatments helped the surviving rice plants to assume faster growth and establishment (Table 4). Roots also differed significantly in their length (Table 4); however, the plants could better establish themselves thereafter with the application of higher doses of additional N, significantly registering higher values of yield components viz. panicle length, number of panicles $\mathrm{m}^{-2}$ and 1000grain weight, compared with the lowest $\mathrm{N}$-dose (Table 5). The crop flowered and matured mostly at the same time, irrespective of additional N-doses (Figure 2(b)). The highest grain yield $\left(6.00 \mathrm{t} \mathrm{ha}^{-1}\right)$ was, however, recorded with the additional dose of $20 \mathrm{~kg} \mathrm{~N} \mathrm{ha}^{-1}\left(\mathrm{~N}_{2}\right)$, which remained at par with $30 \mathrm{~kg} \mathrm{~N} \mathrm{ha}^{-1}\left(\mathrm{~N}_{3}\right)$. The ability for faster recovery and early tiller formation following post-submergence application of higher $\mathrm{N}$-doses might be the reasons for higher grain yields. Maximum grain yield increment under the optimum dose of added $\mathrm{N}$ was obviously due to the highest production of panicles $\mathrm{m}^{-2}$ (310.33), filled grains panicle ${ }^{-1}$ (121.55), panicle length $(23.30 \mathrm{~cm})$ and 1000 -grain weight $(20.08 \mathrm{~g})$ along with minimum spikelet sterility (16.09\%). Plant growth and yield might not only depend on carbohydrate production through photosynthesis but also on mineral absorption by the roots and its assimilation [10]. Significant decline in grain and straw yields was recorded with the lowest $\mathrm{N}$-dose $\left(\mathrm{N}_{1}\right)$. Since a part of applied $\mathrm{N}$, if not absorbed rapidly by plants, might be lost through gaseous emission, percolation or runoff, the lowest N-dose was not enough to meet the crop's demand after submergence [27].

2) Effect of application time: Application of additional $\mathrm{N}$-dose at 7 DAD, when $30-35 \%$ plants started showing at least one green leaf $\left(\mathrm{T}_{2}\right)$, recorded comparatively better survival after submergence $(98.16 \%)$, productive tillers (panicles) $\mathrm{m}^{-2}(312.33)$, filled grains panicle ${ }^{-1}(121.22)$, 1000 -grain weight $(20.83 \mathrm{~g})$, grain yield $\left(6.07 \mathrm{t} \mathrm{ha}^{-1}\right)$ and harvest index (0.412) (Table 5). Time of additional $\mathrm{N}$-application, however, did not exhibit any remarkable variation with respect to flowering and maturity (Figure 2(b)). This might be due to the fact that surviving plants could recover faster and resume their normal vegetative growth, overcoming the damage caused during submergence, when additional dose of $\mathrm{N}$ was applied at $7 \mathrm{DAD}$ [12]. Rice plants could rapidly absorb the additional dose of fertilizer $\mathrm{N}$ applied at $7 \mathrm{DAD}$ which possibly matched with the crop's demand after growth recovery. Next in order was $\mathrm{N}$-application at $10 \mathrm{DAD}\left(\mathrm{T}_{3}\right)$, when $65 \%$ - 70\% plants started showing at least one green leaf. The reductions in grain yield occurred to the tune of $5.38 \%$ and $2.88 \%$ when additional $\mathrm{N}$-dose was applied earlier at 4 $\mathrm{DAD}\left(\mathrm{T}_{1}\right)$ and lately at $10 \mathrm{DAD}\left(\mathrm{T}_{3}\right)$ compared to $7 \mathrm{DAD}$ $\left(T_{2}\right)$. Such yield decline was mainly attributed to the reductions in panicle length, grain filling, number of panicles $\mathrm{m}^{-2}$ and 1000 -grain weight.

Although flooded soil might supply some $\mathrm{N}$ both from the flood water and the soil, rice plants were so stressed after submergence that they could not exploit the nutrients from the flooded soil due to their poor establishment and growth. Therefore, time of $\mathrm{N}$ fertilization during the post-submergence period might be one of the crucial factors for determining the recovery growth which would be very important when stand establishment was completely destroyed by flash flood submergence [8]. Crop plants got damaged at the vegetative stage owing to the destruction of leaf blades and leaf sheaths. New shoots emerged from the tiny stem at the base of damaged plants during the post-submergence period. Good recovery growth during this period could be considered as re-establishment of the crop after flash flood damage [10]. Regrowth and consequently grain yield were much better with $\mathrm{N}$ fertilization at 15 days after the drainage of water than $\mathrm{N}$ application immediately after the drainage of water [28]; however, small additional amount of $\mathrm{N}$ might be applied at any time, preferably at one week after the recession of floods [27,29].

\subsubsection{On-Farm Experiments}

A total of seven participatory farmers cultivated Swar 
Table 6. Impact of seedling age, nursery and post-flood nutrient management treatments on yield and yield attributes of Swarna-Sub1 in farmers' field during wet season of 2011.

\begin{tabular}{|c|c|c|c|}
\hline Treatments & Panicles $\mathbf{~ m}^{-2}$ & Filled grains panicle $^{-1}$ & Grain yield (t ha $\left.{ }^{-1}\right)$ \\
\hline Seedling age $\left(A^{\prime}\right)$ & \multicolumn{2}{|c|}{ Village: Belle } & \\
\hline $\mathrm{A}_{1}^{\prime}: 25$ days & $339.00 \pm 22.07$ & $112.75 \pm 3.61$ & $5.36 \pm 0.33$ \\
\hline $\mathrm{A}_{2}^{\prime}: 35$ days & $371.75 \pm 11.14$ & $133.75 \pm 3.21$ & $6.50 \pm 0.13$ \\
\hline $\mathrm{A}_{3}^{\prime}: 45$ days & $320.00 \pm 16.01$ & $111.00 \pm 2.65$ & $5.33 \pm 0.13$ \\
\hline Nutrient management $\left(N M^{\prime}\right)^{*}$ & \multicolumn{2}{|c|}{ Village: Digha (Dwarbasini) } & \\
\hline $\mathrm{NM}_{1}^{\prime}: 50-25-25 \mathrm{~kg} \mathrm{ha}^{-1}$ & $306.67 \pm 5.03$ & $109.33 \pm 2.52$ & $4.43 \pm 0.23$ \\
\hline $\mathrm{NM}_{2}^{\prime}: 70-35-35 \mathrm{~kg} \mathrm{ha}^{-1}$ & $327.33 \pm 3.51$ & $120.33 \pm 3.21$ & $4.93 \pm 0.08$ \\
\hline $\mathrm{NM}_{3}^{\prime}: 80-40-40 \mathrm{~kg} \mathrm{ha}^{-1}$ & $332.33 \pm 3.21$ & $125.00 \pm 4.58$ & $5.28 \pm 0.17$ \\
\hline Post-submergence $N$ application $\left(N^{\prime}\right)$ at $7 D A D^{*}$ & \multicolumn{3}{|c|}{ Village: Baidyabati Chawk, Serampore-Uttarpara } \\
\hline $\mathrm{N}_{1}^{\prime}: 10 \mathrm{~kg} \mathrm{ha}^{-1}$ & $323.86 \pm 9.92$ & $116.43 \pm 4.16$ & $5.38 \pm 0.18$ \\
\hline $\mathrm{N}_{2}^{\prime}: 20 \mathrm{~kg} \mathrm{ha}^{-1}$ & $355.43 \pm 9.03$ & $137.43 \pm 6.05$ & $6.13 \pm 0.22$ \\
\hline $\mathrm{N}_{3}^{\prime}: 30 \mathrm{~kg} \mathrm{ha}^{-1}$ & $344.14 \pm 6.89$ & $128.71 \pm 3.95$ & $5.84 \pm 0.13$ \\
\hline
\end{tabular}

$\mathrm{NM}^{\prime}$ : Nutrient management in terms of $\mathrm{N}-\mathrm{P}_{2} \mathrm{O}_{5}-\mathrm{K}_{2} \mathrm{O}$; DAD: Days after de-submergence; ${ }^{*} 35$ days old seedlings were transplanted; Figures indicate mean vales \pm standard deviation.

na-Sub1 at the village Baidyabati Chawk under Serampore-Uttarpara Block (Hooghly, West Bengal). N-doses as per treatments were applied at $7 \mathrm{DAD}$ over and above to the recommended fertilizer dose after receding of flood water. All of them recorded higher grain yields with the optimum dose of additional $20 \mathrm{~kg} \mathrm{~N} \mathrm{ha}^{-1}$, followed by 30 and $10 \mathrm{~kg} \mathrm{~N} h a^{-1}$ (Table 6). As a whole, farmers achieved an average grain yield of $6.13 \mathrm{t} \mathrm{ha}^{-1}$ with the additional topdressing of $\left.20 \mathrm{~kg} \mathrm{~N} \mathrm{ha}^{-1}\left(\mathrm{~N}_{2}\right)^{\prime}\right)$, being 5.00 and $13.9 \%$ higher than that of 10 and $30 \mathrm{~kg} \mathrm{~N}$ $\mathrm{ha}^{-1}$, respectively. Such higher grain yields were attributed to the production of more number of panicles $\mathrm{m}^{-2}$ along with improved grain filling (Table 6). The farmers also had a common observation that Swarna-Sub1 started to regenerate vigorously with the emergence of a large number of tillers, following post-submergence application of $20 \mathrm{~kg} \mathrm{~N} \mathrm{ha}{ }^{-1}$ as additional dose. On the other hand, the neighbouring farmers neither used to grow the submergence-tolerant variety, nor did they apply any particular fertilizer doses at a particular time expecting their own common practice, which caused poor crop survival after submergence, leading to nominal yields. The varieties they used for cultivation were completely destroyed in some patches, very few plants survived in some other patches and surviving plants did not show good growth in absence of proper post-flood nutrient management.

\section{Conclusion}

The salient findings of on-station and on-farm trials were 1) raising of healthy and vigorous seedlings using lower seeding density $\left(25 \mathrm{~g} \mathrm{~m}^{-2}\right)$, 2) application of balanced $\mathrm{N}-\mathrm{P}_{2} \mathrm{O}_{5}-\mathrm{K}_{2} \mathrm{O}$ doses @ 80-40-40 kg ha ${ }^{-1}(25 \mathrm{~kg} \cdot \mathrm{N}$ through 5 t FYM ha ${ }^{-1}$ and remaining amounts through chemical fertilizers) in nursery, 3) avoiding use of younger seedlings and rather transplanting them at an optimum age (35 - 40 days' old seedlings), and 4) applying additional $\mathrm{N}$-dose of $20 \mathrm{~kg} \mathrm{ha}^{-1}$ at $7 \mathrm{DAD}$ (when 30\% - 35\% plants would start showing at least one green leaf). These results clearly indicate that proper seedbed management can contribute considerably to maximizing submergence tolerance and grain yield of the rice crop in the main field. Lower seeding rate and balanced rate of $\mathrm{N}_{-} \mathrm{P}_{2} \mathrm{O}_{5}-\mathrm{K}_{2} \mathrm{O}$ in nursery are beneficial, whereas, transplanting of very young seedlings should be avoided. These cost-effective options are expected to further enhance the field performance of Swarna-Sub1 after submergence and thus would be highly helpful to the resource-poor farmers in flash flood-prone areas of West Bengal.

\section{Acknowledgements}

Authors are thankful to the International Rice Research Institute, Los Baňos, Philippines for providing necessary financial and technical support under the European Commission and International Fund for Agricultural Development (EC-IFAD) funded project on "Improved rice crop management for raising productivity in the submergence-prone and salt-affected rainfed lowlands in South Asia”.

\section{REFERENCES}

[1] A. M. Ismail, "Flooding and Submergence Tolerance," In: C. Kole, Ed., Genomics and Breeding for Climate-Resilient Crops, Springer-Verlag, Berlin, Vol. 2, 2013, pp. 269-290. http://dx.doi.org/10.1007/978-3-642-37048-9 7

[2] J. Bailey-Serres, T. Fukao, P. Ronald, A. Ismail, S. Heuer and D. Mackill, "Submergence Tolerant Rice: Sub1's 
Journey from Landrace to Modern Cultivar," Rice, Vol. 3, 2010, pp. 138-147. http://dx.doi.org/10.1007/s12284-010-9048-5

[3] A. M. Ismail, U. S. Singh, S. Singh, M. H. Dar and D. J. Mackill, "The Contribution of Submergence-Tolerant (Sub1) Rice Varieties to Food Security in Flood-Prone Rainfed Lowland Areas in Asia," Field Crops Research, Vol. 152, 2013, pp. 83-93. http://dx.doi.org/10.1016/j.fcr.2013.01.007

[4] M. K. Bhowmick, M. C. Dhara, B. Duary and K. K. Bhadra, "Nursery Management for Achieving Higher Productivity of Hybrid Rice," National Seminar on Recent Advances in Rice Genomics and Biotechnology, Visva-Bharati, Santiniketan, Birbhum, West Bengal, India, 2013, pp. 24-25.

[5] I. Dana and S. Chatterjee, "Swarna-Sub1: A Boon to the Farmers of West Bengal," STRASA News, Vol. 5, 2012, p. 5.

[6] D. J. Mackill, A. M. Ismail, U. S. Singh, R. V. Labiosand and T. R. Paris, "Development and Rapid Adoption of Submergence-Tolerant (Sub1) Rice Varieties," Advances in Agronomy, Vol. 115, 2012, pp. 303-356. http://dx.doi.org/10.1016/B978-0-12-394276-0.00006-8

[7] E. M. Septiningsih, B. C. Y. Collard, S. Heuer, J. BaileySerres, A. M. Ismail and D. J. Mackill, "Applying Genomics Tools for Breeding Submergence Tolerance in Rice," In: R. K. Varshney and R. Tuberosa, Eds., Translational Genomics for Breeding: Abiotic Stress, Yield and Quality, 1st Edition, John Wiley and Sons, New York, 2013, pp. 9-30.

[8] E. S. Ella and A. M. Ismail, "Seedlings Nutrient Status before Submergence Affects Survival after Submergence in Rice," Crop Science, Vol. 46, 2006, pp. 1673-1681. http://dx.doi.org/10.2135/cropsci2005.08-0280

[9] E. S. Ella, M. L. Dionisio-Sese and A. M. Ismail, "Application of Silica at Sowing Negatively Affects Growth and Survival of Rice Following Submergence," Philippine Journal of Crop Science, Vol. 36, 2011, pp. 1-11.

[10] P. C. Ram, M. A. Mazid, A. M. Ismail, P. N. Singh, V. N. Singh, M. A. Haque, U. Singh, E. S. Ella and B. B. Singh, "Crop and Resource Management in Flood-Prone Areas: Farmers' Strategies and Research Development," In: S. M. Haefele and A. M. Ismail, Eds., Proceedings Natural Resource Management for Poverty Reduction and Environmental Sustainability in Fragile Rice-Based Systems, Los Baňos (Philippines), International Rice Research Institute, 2009, pp. 82-94.

[11] R. K. Sarkar, J. N. Reddy, S. G. Sharma and A. M. Ismail, "Physiological Basis of Submergence Tolerance in Rice and Implications for Crop Improvement," Current Science, Vol. 91, 2006, pp. 899-906.

[12] U. S. Singh, M. H. Dar, S. Singh, N. W. Zaidi, M. A. Bari, D. J. Mackill, B. C. Y. Collard, V. N. Singh, J. P. Singh, J. N. Reddy, R. K. Singh and A. M. Ismail, "Field Performance, Dissemination, Impact and Tracking of Submergence Tolerant (Sub1) Rice Varieties in South Asia," SABRAO Journal of Breeding and Genetics, Vol. 45, 2013, pp. 112-131.
[13] H. S. Ravi Kumar, U. P. Singh, S. Singh, Y. Singh, J. M. Sutaliya, U. S. Singh and S. M. Haefele, "Improved Nursery Management Options for Submergence Tolerant (Sub1) Rice Genotypes in Flood-Prone Environments," Third International Agronomy Congress, New Delhi, 2012, pp. 1248-1250.

[14] M. Haefele, A. M. Ismail, D. E. Johnson, C. Vera Cruz and B. Samson, "Crop and Natural Resource Management for Climate-Ready Rice in Unfavourable Environments: Coping with Adverse Conditions and Creating Opportunities," CURE Workshop Climate Change, Siem Reap, 2010.

http://www.fao.org/fileadmin/templates/agphome/docmen ts/IRRI_website/Irri_workshop/LP_16.pdf

[15] G. M. Panaullah, M. S. Rahman and A. L. Shah, "Nutrient Management for Rice in the Flood Prone Ecosystem," In: S. I. Bhuiyan, M. Z. Abedin and B. Hardy, Eds., Rice Research and Development in the Flood-Prone Ecosystem, Proceedings International Workshop on FloodProne Rice Systems, Gazipur, 2001, pp. 225-235.

[16] Anonymous, "Methods Manual: Soil Testing in India," Department of Agriculture and Cooperation, Ministry of Agriculture, Government of India, New Delhi, 2011, p. 208.

[17] K. A. Gomez and A. A. Gomez, "Statistical Procedures for Agricultural Research," 2nd Edition, A Wiley-InterScience Publication (John Wiley and Sons), New York, 1984.

[18] D. M. TeKrony and D. B. Egli, "Relationship of Seed Vigour to Crop Yield: A Review," Crop Science, Vol. 31, 1991, pp. 816-822.

http://dx.doi.org/10.2135/cropsci1991.0011183X0031000 30054x

[19] M. K. Bhowmick, B. Duary, C. Kundu, M. C. Dhara and P. K. Biswas, "Rice Production Technologies for Sustaining Self-Sufficiency and Strengthening Rural Economy in West Bengal," In: P. K. Chattopadhyay and S. Bhattacharya, Eds., Challenges of Livelihood and Inclusive Rural Development in the Era of Globalization, New Delhi Publishers, 2013, pp. 401-417.

[20] P. Singh, "Nutrient Management in Nursery for Improving Submergence Tolerance in Swarna-Sub1 Rice (Oryza sativa L.)," M. Sc. Dissertation, Narendra Deva University of Agriculture and Technology, Kumarganj, Faizabad (U.P.), 2011.

[21] S. Yadav, "Effect of N-Enriched Seedling on Submergence Tolerance of $S U B 1$ and Non SUB1 Rice (Oryza sativa L.) Varieties," M. Sc. Dissertation, Narendra Deva University of Agriculture and Technology, Kumarganj, Faizabad (U.P.), 2012.

[22] A. Mishra and V. M. Salokhe, "Seedling Characteristics and the Early Growth of Transplanted Rice under Different Water Regimes," Experimental Agriculture, Vol. 44, 2008, pp. 1-19. http://dx.doi.org/10.1017/S0014479708006388

[23] M. Himeda, "Cultivation Technique of Rice Nursling Seedlings: Review of Research Papers and its Future Implementation," Agriculture and Horticulture, Vol. 69, 1994, pp. 679-683,791-796. 
[24] H. A. Kordon, "Patterns of Shoot and Root Growth in Rice Seedlings Germinating under Water," Journal of Applied Ecology, Vol. 11, 1974, pp. 685-690. http://dx.doi.org/10.2307/2402218

[25] R. Sasaki, "Characteristics and Seedlings Establishment of Rice Nursling Seedlings," Japanese Agricultural Research Quarterly, Vol. 38, 2004, pp. 7-13.

[26] P. N. Singh, P. C. Ram, A. Singh and B. B. Singh, "Effect of Seedling Age on Submergence Tolerance of Rainfed Lowland Rice," Annals of Plant Physiology, Vol. 19, 2005, pp. 22-26.

[27] A. K. Pandey, "Nitrogen Management for $S U B 1$ Rice Varieties in Submerged Rice Field (Oryza sativa L.)," M.
Sc. Dissertation, Narendra Deva University of Agriculture and Technology, Kumarganj, Faizabad (U.P.), 2013.

[28] A. R. Gomosta, "Crop Establishment in the Flood-Prone Ecosystem," In: S. I. Bhuiyan, M. Z. Abedin and B. Hardy, Eds., Rice Research and Development in the FloodProne Ecosystem, Proceedings International Workshop on Flood-Prone Rice Systems, Gazipur, Bangladesh, 2001, Los Baňos (Philippines), pp. 205-223.

[29] D. J. Mackill, A. M. Ismail and R. V. Labios, "Guidelines of Submergence-Tolerant Rice Varieties: Production and Management," Raising Productivity in Rainfed Environments: Attacking the Roots of Poverty, Diliman, Quezon City, 2011. 